\title{
Perawatan Impaksi Gigi Premolar Pertama Mandibula Pada Maloklusi Angle Klas II Divisi 2 Subdivisi Dengan Teknik Begg
}

\author{
Apreka Tigor Kusumasmara*, Wayan Ardhana**, dan Christnawati \\ * Program Studi Ortodonsia PPDGS Fakultas Kedokteran Gigi Univeristas Gadjah Mada \\ **Bagian Ortodonsia Fakultas Kedokteran Gigi Univeristas Gadjah Mada \\ *Jl Denta no 1 Sekip Utara, Yogyakarta, e-mail: atkusumasmara@yahoo.com
}

\begin{abstract}
ABSTRAK
Impaksi gigi terjadi karena gigi gagal untuk erupsi secara sempurna pada posisinya akibat terhalang oleh gigi lain maupun jaringan lunak atau padat di sekitarnya. Gigi yang sering mengalami impaksi adalah gigi geraham ketiga rahang bawah, gigi kaninus rahang atas, dan gigi premolar kedua. Impaksi premolar sering terjadi karena pencabutan prematur dari gigi geraham desidui. Gigi premolar pertama jarang terjadi impaksi dibandingkan premolar kedua. Tujuan laporan kasus adalah untuk memaparkan penatalaksanaan perawatan untuk mengkoreksi impaksi gigi premolar pertama mandibula menggunakan alat cekat teknik Begg tanpa prosedur bedah. Pria 21 tahun mengeluhkan gigi yang berjejal pada rahang atas dan rahang bawah. Gigi kaninus desidui kiri rahang atas dan rahang bawah belum tanggal. Diagnosis pasien adalah Maloklusi Angle Klas II divisi 2 bimaksiler protrusif dengan hubungan skeletal klas II, gigi anterior maksila retrusif, disertai impaksi gigi premolar pertama mandibula kiri. Perawatan dilakukan dengan menggunakan alat cekat teknik Begg dan pencabutan gigi desidui, Kesimpulan, impaksi gigi premolar pertama mandibula dapat tercapai pada tahap pertama teknik Begg tanpa pendekatan tindakan bedah, tahap selanjutnya yang akan dicapai adalah tahap memperbaiki inklinasi aksial gigi.
\end{abstract}

Maj Ked Gi. Juni 2013; 20(1): 92 - 98.

Kata Kunci: Impaksi, premolar pertama mandibula, persistensi, gigi desidui, teknik Begg,

\begin{abstract}
Treatment Of Class II Division 2 Angle Malocclusion With Mandibular Premolar Tooth Impaction Using Begg Technique. Tooth impaction is a tooth that fails to erupt perfectly to its position because of the other tooth, surrounding soft or hard tissue that blocks its eruption. Premolar often fails to erupt due to a premature extraction of deciduous molar. This case study aims to illustrate the treatment of mandibular first premolar impaction using Begg technique for fixed appliance. The experiment was conducted to a 21 year-old male patient who complained about his crowding of upper and lower teeth, also the persistence of his upper and lower left deciduous canine. The case was diagnosed as class II division 2 angle malocclusion with bimaxillary protrusion with class II skeletal relation, and maxillary anterior teeth retrusion. The left mandibular of first premolar teeth was impacted. The treatment using Begg technique has helped to fix the appliance with the extraction of the deciduous teeth. From the evaluation, it can be concluded that the treatment of impacted mandibular first premolar is achieved on the first stage of Begg technique without surgical approach. The next objective of the treatment is to correct the teeth axis.

Maj Ked Gi. Juni 2013; 20(1): 92 - 98.
\end{abstract}

Keywords: Impacted, mandibular first premolar, persistency, deciduous teeth, Begg technique

\section{PENDAHULUAN}

Pada masa kini penampilan fisik dan senyum bagi masyarakat menjadi salah satu faktor penting untuk meningkatkan kualitas hidup. Penampilan fisik yang baik dapat meningkatkan psikososial seseorang dalam masyarakat. Keadaan gigi anterior yang kurang baik dan berjejal mempengaruhi senyum seseorang dan mengakibatkan berkurangnya daya tarik. Oleh karena itu ortodontis berperan penting dalam memenuhi kebutuhan tersebut. ${ }^{1}$
Maloklusi dapat menyebabkan gangguan fungsi pengunyahan, bicara, penelanan, serta masalah psikologis. Gigi berjejal merupakan keadaan maloklusi yang paling sering terjadi dan menjadi alasan pasien ingin memperoleh perawatan ortodontik. ${ }^{2}$ Tujuan perawatan ortodontik adalah mendapatkan keharmonisan bentuk wajah, relasi, fungsi pengunyahan dan kestabilan hasil perawatan, sehingga meningkatkan fungsi gigi, estetik wajah dengan susunan gigi yang teratur, stabil dan seimbang. ${ }^{3}$ 
Impaksi gigi adalah kegagalan gigi untuk erupsi secara sempurna pada posisinya akibat terhalang oleh gigi lain maupun jaringan lunak atau padat di sekitarnya. ${ }^{4}$ Gigi yang sering mengalami impaksi gigi adalah gigi geraham ketiga rahang bawah, dan gigi kaninus rahang atas. Terdapat beberapa faktor yang diduga menjadi penyebab terjadinya impaksi gigi, seperti kekurangan ruang, kista, gigi supernumerari, retensi gigi sulung, infeksi, trauma, anomali dan kondisi sistemik. ${ }^{5}$

Impaksi gigi premolar dengan prevalensi 0,5\% dapat terjadi karena adanya faktor lokal seperti terjadinya pergerakan ke mesial dari gigi permanen akibat premature loss gigi geraham desidui, benih gigi premolar yang posisinya ektopik, atau dapat terjadi karena adanya kista dentigerus. ${ }^{6}$ Terjadinya impaksi sering diasosiasikan terjadi akibat kurangnya ruang untuk gigi tersebut menempati posisinya, oleh karena itu gigi impaksi dapat erupsi dengan sendirinya dengan syarat disediakan atau memiliki ruang yang cukup gigi tersebut. ${ }^{7.8}$

Terdapat beberapa pilihan perawatan gigi impaksi yaitu operasi pencabutan, transplantasi, observasi dan operasi exposure untuk membuka gigi yang impaksi kemudian menggerakkannya ke dalam lengkung gigi dengan alat ortodontik.Salah satu teknik perawatan ortodontik adalah dengan teknik Begg. Perawatan teknik Begg menggunakan gaya yang ringan untuk menggerakkan gigi dan hasil pergerakkannya adalah tipping. ${ }^{9} 10$ Artikel ini ini memaparkan perawatan impaksi gigi premolar pertama mandibula pada maloklusi Angle kelas II Divisi 2 subdivisi dengan menggunakan alat cekat Begg.

\section{STUDI KASUS}

Seorang pria berumur 21 tahun datang ke klinik Ortodonsia RSCM Prof. Soedomo dengan keluhan gigi berjejal pada rahang atas dan rahang bawah, gigi kaninus kiri bawah yang miring ke belakang. Pemeriksaan ekstraoral menunjukkan profil pasien cembung dengan bentuk muka mesoprosop (Gambar 1). Pemeriksaan intra oral memperlihatkan bentuk lengkung gigi rahang atas dan bawah parabola simetris. Susunan gigi segmen anterior berjejal disertai deep bite pada regio anterior, scissor bite pada regio gigi 14, gigi 33 tipping ke distal menempati posisi gigi 34, dan gigi 34 tidak terlihat secara klinis. Pada rahang atas dan rahang bawah masih terdapat gigi desidui 63, dan 73 yang kesundulan. Pemeriksaan foto rontgen periapikal pada regio 34 menunjukkan gigi 34 mengalami impaksi dengan posisi vertikal akibat gigi 33 yang tipping ke distal (Gambar 3 dan 4). Berdasarkan foto rontgen shift sketch menunjukkan gigi 34 berada di sisi lingual.

Pada pemeriksaan sefalometri disimpulkan pasien memiliki hubungan skeletal klas II dengan bimaksiler protrusif serta bidental retrusif dengan relasi rahang yang berotasi berlawanan jarum jam.

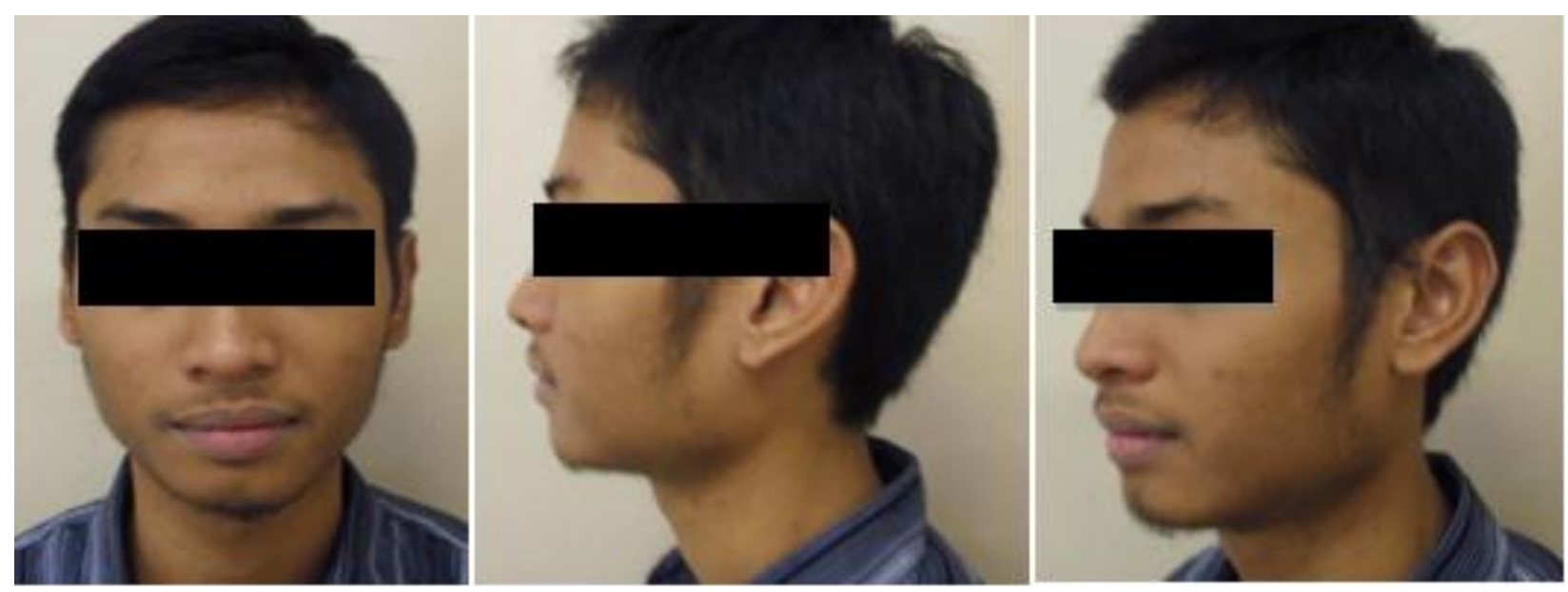

Gambar 1. Foto ekstraoral sebelum perawatan 


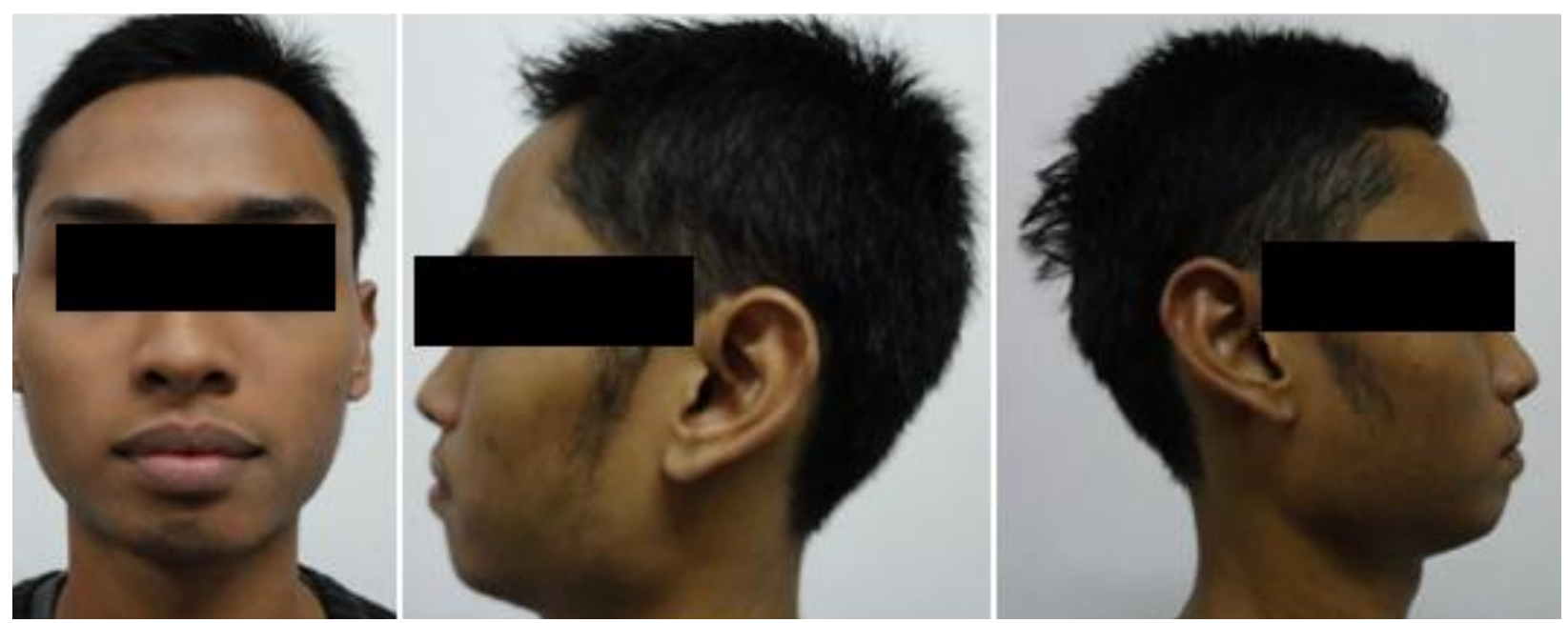

Gambar 2. Foto ekstraoral setelah 1 tahun perawatan

Rencana perawatan untuk pasien tersebut adalah pencabutan gigi 38 yang impaksi, gigi 63 dan 73 yang kesundulan. Untuk mengatasi diskrepansi pada lengkung gigi dilakukan protraksi dan pengasahan Interproximal. Perawatan ortodontik dilakukan dengan menggunakan alat ortodontik cekat teknik Begg. Tahap perawatan disusun berdasarkan 3 tahap pada metode teknik Begg. Tujuan tahap pertama perawatan teknik Begg adalah mengatur letak gigi dengan koreksi buko-lingual (unravelling), memperbaiki ketidakteraturan dalam arah vertikal (levelling). Tahap awal perawatan dilakukan untuk mengkoreksi gigi regio anterior yang berjejal dengan penggunaan loop vertikal dan karet elastik intermaksiler dari kaitan buccal tube molar pertama rahang bawah ke kaitan mesial gigi kaninus. Gigi 33 yang tipping ke distal ditegakkan ke mesial agar diperoleh ruangan yang cukup untuk mengkoreksi gigi 34 yang impaksi (Gambar 5, 6, 7 dan 8). Tahap II penutupan ruang tidak diperlukan sehingga dapat dilanjutkan tahap ketiga perbaikan aksial gigi. Setelah selesai tahap pertama langsung dilanjutkan ke tahap ketiga dengan tujuan memperbaiki aksial gigi. Perawatan diakhiri dengan pemasangan retainer.
Perawatan diawali dengan menggunakan busur kawat diameter 0,014" hingga diameter 0,020”. Gigi rahang atas dan rahang bawah dilakukan levelling dan unravelling dengan penggunaan loop vertical di antara gigi 13 dan 12, 22 dan 23, 33 dan 32, 31 dan 41, 42 dan 43 pada australian wire 0,014" yang dilengkapi dengan kaitan melingkar tepat di mesial braket kaninus.

Koreksi rotasi gigi 23 dilakukan dengan sistim couple dengan menambahkan braket dibagian lingual gigi 23, sedangkan gigi 33 ditegakkan ke mesial menggunakan open coil spring diikuti rotasi dengan sistim couple terlihat pada gambar 6 .

Tahap kedua sistem Begg tidak ada karena ruang bekas pencabutan gigi 63 dan 73 telah menutup akibat tahap leveling dan unravelling . Pada tahap ketiga perbaikan inklinasi gigi digunakan plain archwire 0,020" dengan anchore bend $15^{\circ} \mathrm{di}$ mesial molar pertama, kaitan melingkar pada mesial braket kaninus, uprighting spring untuk koreksi mesial dan distal tilting, rotating spring untuk koreksi rotasi gigi dan elastik intermaksiler klas II 5/16" 2 oz. Perawatan diakhiri dengan pemakaian retainer. Perkembangan perawatan dapat dilihat pada foto ekstraoral setelah 1 tahun perawatan (Gambar 2). 


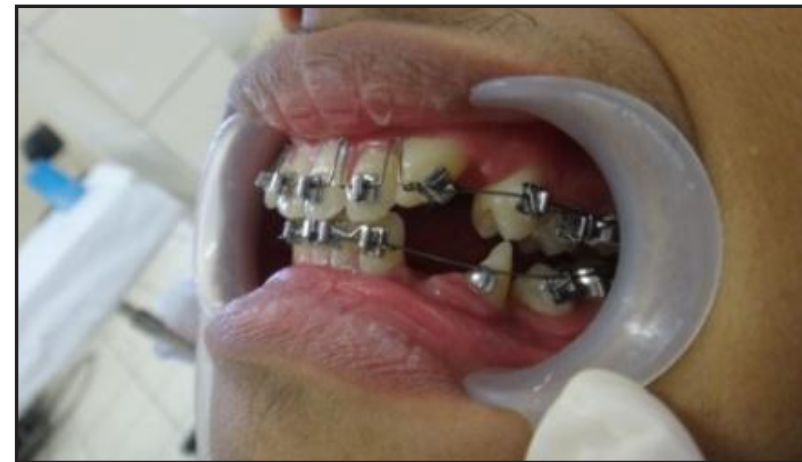

Gambar 3. Foto intraoral awal perawatan

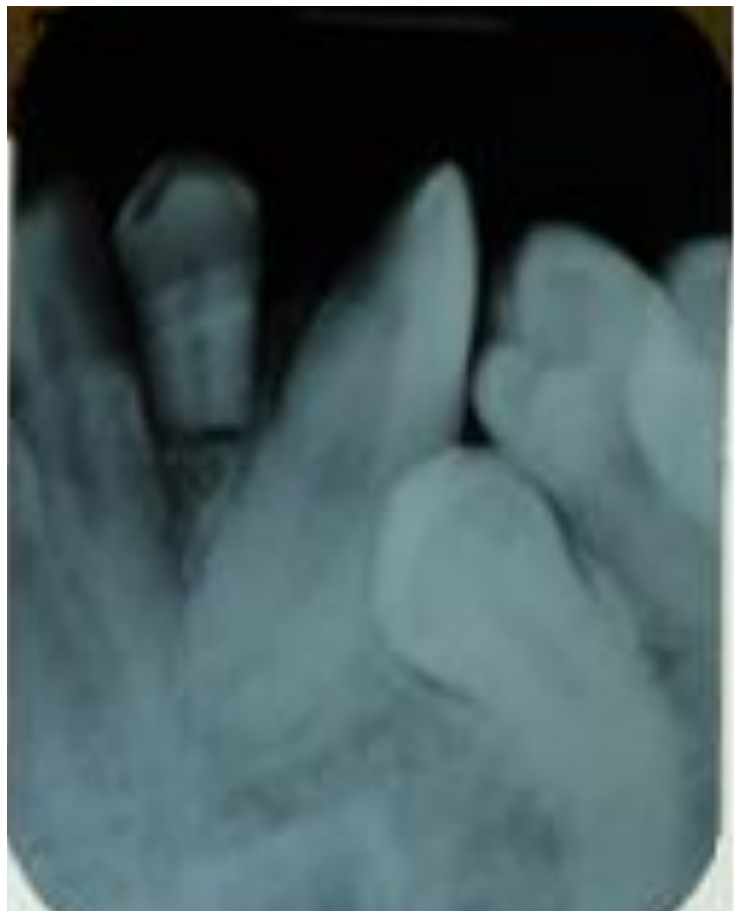

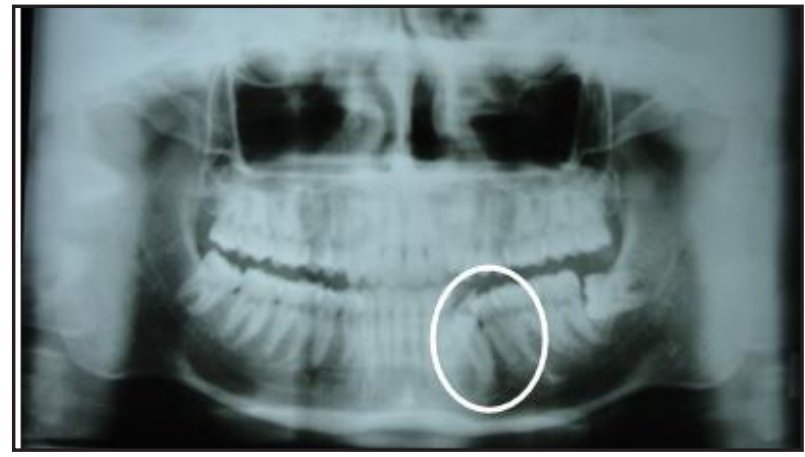

Gambar 4. Foto OPG sebelum perawatan, gigi 34 tampak tidak dapat tumbuh akibat terhalang oleh gigi 33

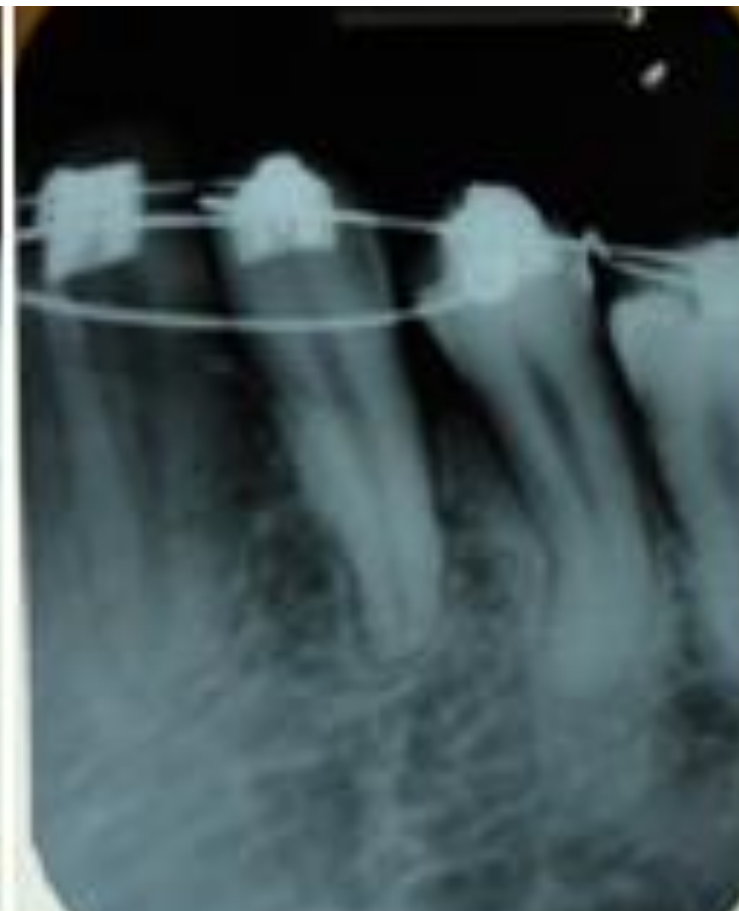

Gambar 5. Foto inset sebelum dan sesudah menunjukkan perubahan
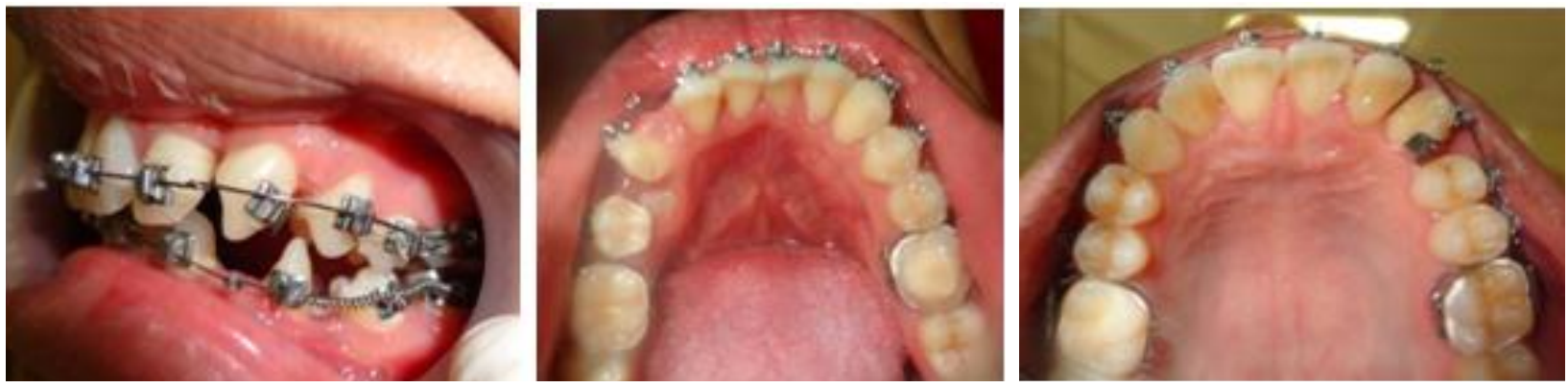

Gambar 6. Foto intraoral 3 bulan perawatan 
Maj Ked Gi. Juni 2013; 20(1): 92-98

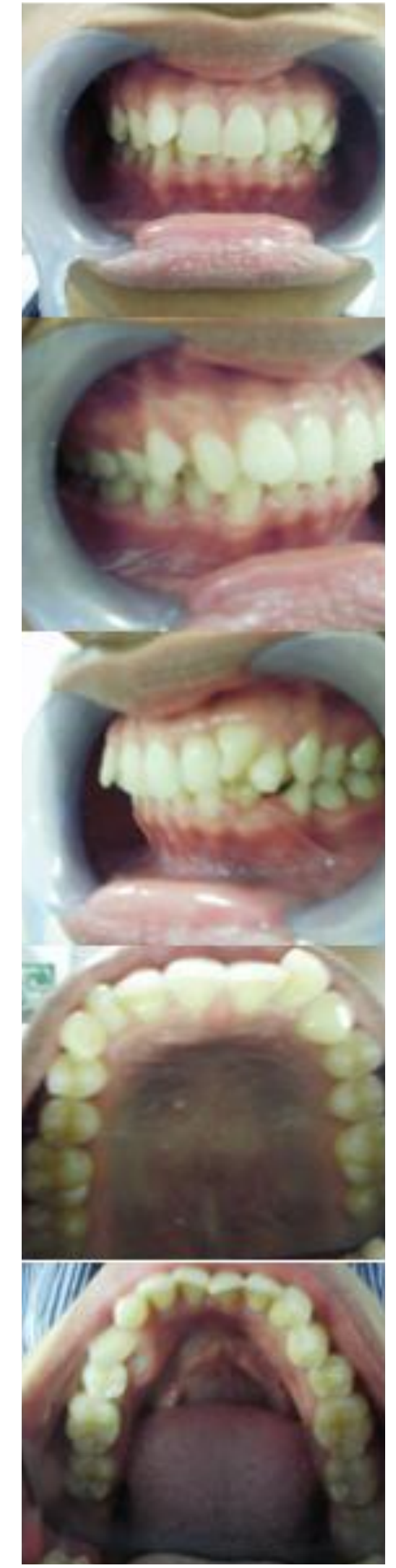

(A)

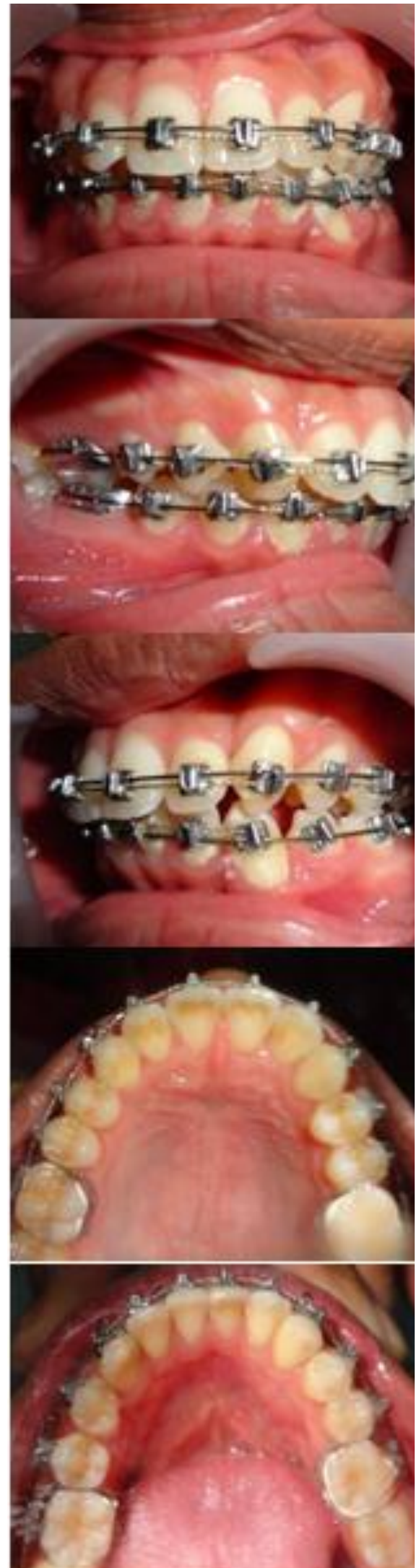

(B)

Gambar 7. Foto intraoral sebelum (A) dan setelah 1 tahun perawatan (B) 

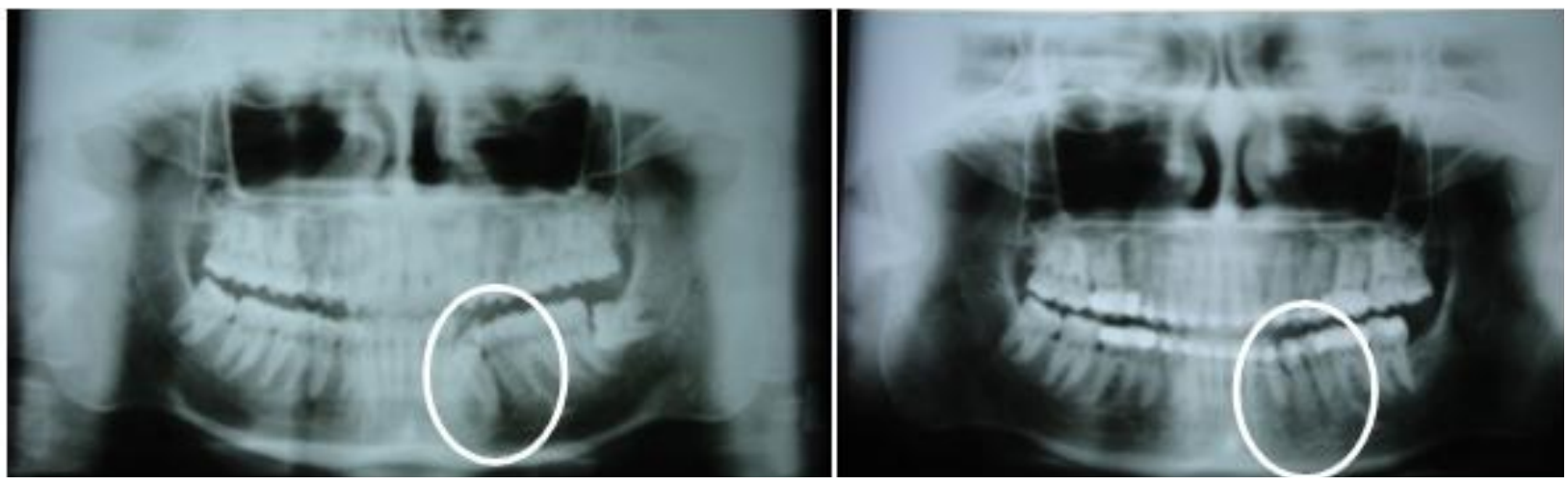

Gambar 8. Foto OPG sebelum dan setelah 1 tahun perawatan

\section{PEMBAHASAN}

Berdasarkan pemeriksaan klinis, analisis model, dan sefalometri, kasus merupakan maloklusi Angle Klas II divisi 2 subdivisi dengan hubungan skeletal klas II dengan bimaksiler protrusif, retrusif gigi anterior maksila, disertai malrelasi scissorbite, open bite, deepbite, crowding, dan impaksi gigi 34.

Impaksi gigi premolar kemungkinan terjadi karena faktor lokal seperti terjadinya pergerakan ke mesial gigi permanen akibat premature loss gigi geraham desidui, posisi benih gigi premolar ektopik, atau karena adanya kista dentigerus. ${ }^{6}$ Penyebab terjadinya impaksi gigi 34 pada kasus ini adalah terjadinya persistensi gigi 73 , keadaan tersebut menyebabkan erupsi gigi 33 tipping ke distal, menempati posisi gigi 34 .

Loop vertikal pada kawat busur digunakan pada awal perawatan, gigi anterior mengalami levelling dan unravelling sehingga keadaan scissorbite pada regio gigi 14 terkoreksi. Koreksi deepbite yang dilakukan dengan intrusi dan protraksi regio anterior menghasilkan pendataran kurva spee. Koreksi gigi 23 yang rotasi membutuhkan gaya couple dengan cara memberi tambahan braket pada sisi lingual gigi 23. Elastik kemudian dikaitkan dari braket ini pada cleats di lingual molar band. Penegakkan dan rotasi gigi 33 dilakukan dengan open coil spring untuk menimbulkan gaya rotasi dan tipping ke mesial dengan mendorong braket Begg yang ditempatkan pada permukaan mesial gigi karena permukaan buccal gigi 33 berkontak pada sisi mesial gigi 35 . Penegakkan ke mesial gigi 33 juga akan menyediakan ruang untuk gigi 34 .
Salah satu cara perawatan ortodontik gigi impaksi adalah menyediakan ruang pada lengkung gigi dan diharapkan gigi dapat erupsi dengan sendirinya, jika tidak terjadi erupsi spontan maka dapat dilakukan traksi ortodontik dengan bantuan tindakan bedah. ${ }^{7}$ Keadaan gigi impaksi dapat erupsi spontan terutama terjadi pada pasien yang masih muda dengan menghilangkan hambatan yang berada di jalur erupsi gigi yang impaksi. Hal ini seperti yang dilaporkan pada kasus impaksi gigi kaninus oleh Kokich. ${ }^{11}$

Koreksi rotasi dengan sistim couple memerlukan reposisi braket yang dilakukan secara simultan dengan penegakkan gigi 33 ke mesial. Ruang yang terbentuk diantara gigi 33 dan 35 menyebabkan gigi 34 dapat erupsi dengan sendirinya. Lingual button kemudian ditempelkan pada permukaan gigi 34 yang mulai terlihat dan diikatkan dengan kawat ligatur ke kawat busur untuk mengarahkan gigi 34 ke posisi lengkung rahang bawah yang ideal.

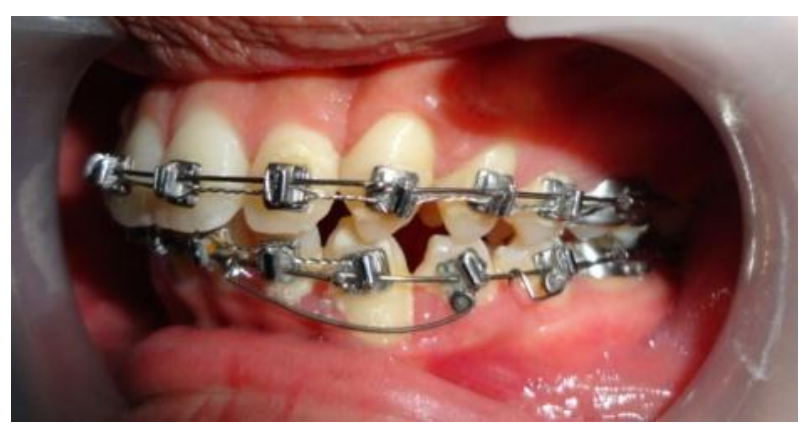

Gambar 9. Foto intraoral upraighting pada gigi 34 dan 35 
Setelah gigi 34 erupsi sempurna dan berada pada lengkung rahang bawah, tahap selanjutnya adalah koreksi aksial gigi 34. Pada gigi 34 dan 35 di beri uprighting spring pada kawat busur 0,020" Australian wire untuk menggerakkan akar gigi ke mesial (Gambar 9). Proses upraighting gigi 34 masih berlangsung karena berdasarkan foto ronsen periapikal akar gigi 34 mengalami dilaserasi kearah mesial sehingga membutuhkan waktu lebih lama.

\section{KESIMPULAN}

Perawatan gigi impaksi dengan alat ortodontik memerlukan diagnosis dan rencana perawatan yang tepat dan teliti. Koreksi impaksi gigi 34 dapat tercapai pada tahap pertama perawatan dengan alat cekat teknik Begg dengan sejumlah modifikasi dan tanpa perlu dilakukan tindakan pembedahan. Perawatan masih dalam tahap ketiga yaitu koreksi aksial gigi.

\section{DAFTAR PUSTAKA}

1. Graber LW, Vanarsdall RL Vig, Katherine WL. Orthodontic current principles and techniques. St.Louis: The C.V. Mosby Company; 2012. H. 56162, 582-83.

2. Emeria AM, Anne M, Kuijpers -Jagtman, Martin AV, Emil NK. Perceptions of dental attractiveness and orthodontic treatment need among tanzanian children. American Journal of Orthodontics and
Dentofacial Orthopedics. 2003: Volume 125. Number 4.

3. Proffit WR, Fields HW. Contemporary orthodontics. Ed 4. St.Louis : Mosby Year Book; 2004: H.133, 248-53.

4. Peterson LJ. Contemporary oral maxillofacial surgery. $4^{\text {th }}$ Ed. 2003. Mosby: St.Louis.

5. Pertiwi ASP, Sasmita IS. Penatalaksanaan kekurangan ruangan pada gigi impaksi secara pembedahan dan ortodontik. Indonesian Jurnal of Oral and Maxillofacial Surgeon. 2004; 229-30

6. Andreasen JO, Andreasen JO, Petersen JK, Laskin DM. Textbook and color atlas of tooth impactions; diagnosis, treatment and prevention. Copenhagen: Munksgaard; 1997. H. 177-95.

7. Burch J, Ngan P, Hackmar A. Diagnosis and treatment planning for uneruptedpremolars. Pediatr Dent. 1994; 16(2): 89-95.

8. Becker A. The orthodontic treatment of impacted teeth, London: Martin Dunitz Ltd; 1998. H. 6-7.

9. McDonald F, Yap WL. The surgical exposure and application of direct traction of unerupted teeth. Am J Orthod. 1986; 89: 331-40.

10. Begg PR, Kesling PC. Begg Orthodontic Theory and Technique. Ed 2. Philadelphia : W.B. Saunders Co; 1977.

11. Vincent GK, Preorthodontic uncovering and autonomous eruption of palatally impacted maxillary canines. Semin Orthod. 2010; 6: 205-211. 